\title{
Sustainable production with obtaining glucosamine from crab exoskeletons
}

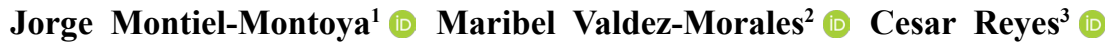 \\ Hebert Jair Barrales-Cureño ${ }^{3^{*}}$ (i)
}

\begin{abstract}
${ }^{1}$ Centro Interdisciplinario de Investigación para el Desarrollo Integral Regional, Instituto Politécnico Nacional Unidad Sinaloa, Boulevard Juan de Dios Bátiz 250, Col. San Joachín, Guasave, Sinaloa, México.

${ }^{2}$ Consejo Nacional de Ciencia y Tecnología (CONACyT). Centro Interdisciplinario de Investigación para el Desarrollo Integral Regional, Instituto Politécnico Nacional, Biotechnology Department, Agricultural Metabolomics Area, México.

${ }^{3}$ División de Ciencias Naturales, Universidad Intercultural del Estado de Puebla (UIEP), Calle Principal a Lipuntahuaca, Lipuntahuaca, Huehuetla, Puebla, México. E-mail: hebert.jair@uiep.edu.mx. "Corresponding author.
\end{abstract}

\begin{abstract}
Two chemical treatments, five enzymatic (pectinase, lipase, hemicellulase, hemicellulose-cellulase or lipase-pectinase) and one microbiological (Bacillus subtilis) treatment were evaluated to obtain glucosamine hydrochloride (Gluc-HCl) from the chitin obtained from crab (Callinectes bellicosus) exoskeletons. Chemical treatments were referred as Method A ( $\mathrm{HCl}$ hydrolysis during 75 min at $90^{\circ} \mathrm{C}$ ) and Method B (HCl hydrolysis during $20 \mathrm{~min}$ and $14 \mathrm{~h}$ of rest). Glucosamine and, in some cases, $N$-acetyl-D-glucosamine were identified and quantified by HPLC. Treatments with the greater concentrations of Gluc-HCl in descending order were: lipase (94.4 mg/g), microbiological $(45.7 \mathrm{mg} / \mathrm{g})$, lipase-pectinase $(22.9 \mathrm{mg} / \mathrm{g})$, hemicellulase-cellulase $(20.9 \mathrm{mg} / \mathrm{g})$, hemicellulase $(15.3 \mathrm{mg} / \mathrm{g})$, pectinase $(10.7 \mathrm{mg} / \mathrm{g})$, Chemical A $(7.3 \mathrm{mg} / \mathrm{g})$ and Chemical B (7.3mg/g). In terms of yield, the best treatments in descending order were: pectinase (94\%), microbiological (94\%), hemicellulase (92\%), lipase (91\%), Chemical B (88\%), lipase-pectinase (88\%), hemicellulase-cellulase (86\%) and Chemical A (28.5\%). The two most profound treatments were lipase and microbiological, so they are proposed as part of a viable method to produce Gluc-HCl from $\mathrm{crab}$ exoskeletons; they are ecofriendly procedures and could add value to the crab's productive chain.
\end{abstract}

Key words: Callinectes bellicosus, extraction methods, glucosamine hydrochloride, HPLC analysis.

Produção sustentável para obtenção de glucosamina a partir de exoesqueletos de caranguejo

RESUMO: Dois tratamentos químicos, cinco enzimáticos (pectinase, lipase, hemicelulase, hemicelulose-celulase ou lipase-pectinase) e um microbiológico (Bacillus subtilis) foram avaliados para obter o cloridrato de glucosamina (Gluc-HCl) da quitina obtida a partir de exoesqueletos de caranguejo (Callinectes. Bellicosus). Os dois tratamentos químicos foram nomeados como método A (hidrólise de HCl para 75 min a $90^{\circ} \mathrm{C}$ ) e método B (hidrólise de HCl para 20 min e 14 h de repouso). A Glucosamina e, em alguns casos, $N$-acetil-D-glucosamina foram identificados e quantificados por HPLC. Os tratamentos em que as melhores concentrações de Glucosamina-HCl foram obtidas, em ordem decrescente: lipase (94,4 mg/g), microbiológica (45,7 mg/g), lipase-pectinase (22,9 mg/g), hemicelulase-celulase (20,9 mg/g), hemicelulase (15,3 mg/g), pectinase (10,7mg/g), Quïmica A (7,3 mg/g) e Quïmica B (7,3 mg/g). Em termos de produtividade, os melhores tratamentos em ordem decrescente foram: pectinase (94\%), microbiológica (94\%), hemicelulase (92\%), lipase (91\%), química B (88\%), lipase-pectinase $(88 \%)$, hemicelulase-celulase (86\%) e produto químico A (28,5\%). Os dois melhores tratamentos foram lipase e microbiológicos, propostos como método viável para obtenção de Gluc-HCl a partir de exoesqueletos de caranguejo; cumprem procedimentos ecologicamente corretos e podem agregar valor à cadeia produtiva do caranguejo.

Palavras-chave: Callinectes bellicosus, métodos de extração, cloridrato de glucosamina, análise HPLC.

\section{INTRODUCTION}

Each year, approximately 100 trillion tons of chitin are produced in nature (FAKHRAD \& RENGIN, 2018; ELIEH-ALIKOMI \& HAMBLIM, 2016), representing an appropriate biomass resource for the production of glucosamine (SIBI et al., 2013). Worldwide, the crab-processing industry generates waste or byproducts (approximately 50\% of processed raw material) that in some regions create problems regarding collection, disposal and environmental contamination (SHAHIDI \& SYNOWIECKI, 1991; XU et al., 2008).

These regions include the northwest of Mexico, where the by-products generated (exoskeletons mainly) by the crab-processing industry (Callinectes bellicosus) are not harvested; although, they represent an excellent source of chitin from which glucosamine can be extracted and with this add more value to the crab-production chain. According to CONAPESCA, from 2012 to 2016, crab production rose by 30 thousand tons, more than $50 \%$, reaching from 21 to 51 thousand tons 
(CONAPESCA, 2018), of which a significant amount is processed; until 2011, roughly nine thousand tons per year was yielded (SAGARPA, 2011).

Conversely, glucosamine $\left(\mathrm{C}_{6} \mathrm{H}_{13} \mathrm{NO}_{5}\right)$ is an amino-sugar that acts as a precursor during the synthesis of biomolecules, especially in the glycosylation of proteins and lipids. In the human body, it is the fundamental construction element for the biosynthesis of various compounds necessary for the formation and repair of cartilage tissue, such as glycolipids and glycoproteins, including proteoglycans (MILLER \& CLEGG, 2011; JAMIALAHMADI et al., 2014). For several decades, it has been commercialized in the form of glucosamine hydrochloride ( $\mathrm{Gluc}-\mathrm{HCl})$, $\mathrm{N}$-acetyl-D-glucosamine and glucosamine sulfate without observing differences in the effectiveness of these forms of presentation and having an extensive market around the world (HENROTIN et al., 2012).

It is used to relieve symptoms of leg pain, rheumatoid arthritis, inflammatory bowel disease, such as ulcerative colitis and Crohn's disease, and temporomandibular joint disorders (ANASTASSIADES et al., 2013; ROVATI et al., 2015). Scientific investigation suggested there is a benefic effect of glucosamine against osteoarthritis, and glucosamine- $\mathrm{HCl}$ consumption has even been proposed as a protector of erythrocyte damage caused by free radicals (JAMIALAHMADI et al., 2014; ROVATI et al., 2015); however, the evidence of the bioprotector effect of glucosamine for the treatment of other diseases is not clear.

Glucosamine can be obtained from various sources: from the exoskeleton of arthropods, from the cell wall of fungi and, as already mentioned, from the shell of various crustaceans, like shrimp and crab (SIBI et al., 2013). In general, glucosamine has been commercially prepared by acid or alkali hydrolysis $(\mathrm{HCl})$ of chitin $[\beta$ - poly- $(1,4)-\mathrm{N}$-acetylglucosamine], which is the most abundant substance within the exoskeletons of crustaceans; chitin is combined with proteins and calcium carbonate, substances that have to be removed to purify glucosamine (SIBI et al., 2013; HASSAINIA et al., 2017). Yet, this chemical method to hydrolysate chitin has the disadvantage whereby large amounts of acid solutions and other contaminants must be employed; therefore, it has been necessary to find alternative methods of extraction. This led to the use of enzymatic methods with individual enzymes involved or conjugated, such as pectinase, hemicellulase, cellulase, $\beta$-Dglucosaminidasas and even lipases, have proven exo- and endochitinase activity at different levels and various reaction conditions; fermentation methods have also been employed in the solid state with species of Bacillus, Serratia and Penicillium, where the action of certain enzymes mentioned before are utilized; these methods are friendly to the environment, relatively inexpensive and produce better yields than chemical methods (YALPANI et al., 1994; LEE et al., 2008; SUN et al., 2013; NIDHEESH et al., 2015; SALEEM et al., 2016). It is of interest to search for new enzymes, and combinations of them that are chitin degraders and obtain higher glucosamine yields than those currently obtained by particular research groups.

The aim of the research was to evaluate chemical, enzymatic and microbiological methods for obtaining Gluc-HCl from chitin from crab exoskeletons to develop a viable method with low environmental impact that offers added value to the waste generated by crab-processing companies.

\section{MATERIALS AND METHODS}

The present study was carried out in the Quality Control and Research Laboratory of the crab-processing company, Mexi Food S.A. of C.V., and the Department of Agricultural Biotechnology of CIIDIR-IPN, Sinaloa Unit.

\section{Materials}

Analytical scale (Ohaus); vacuum pump (Busch); heating plates (Fisher Scientific); oven (YamatoDX302) set of micro samplers; precision pipettor; enzymes: hemicellulase, cellulase, lipase and pectinase (Sigma-Aldrich, St. Louis, USA), strain Bacillus subtilis; biftalate buffer $\mathrm{pH} 4$; phosphate buffer $\mathrm{pH} 7$; acetonitrile; water - chromatographic grade; and distilled water.

\section{Sample processing}

Crab exoskeletons were provided by the processing company, Mexi Food S.A. de C.V., from the municipality of Guasave, Sinaloa, Mexico. They were washed, dried, ground finely in a mortar and kept refrigerated at $4^{\circ} \mathrm{C}$ until they were used. To obtain chitin, a chemical procedure was followed: demineralization was first carried out, starting with $250 \mathrm{~g}$ of crab exoskeleton powder, to which $1.375 \mathrm{~L}$ of $2 \mathrm{~N} \mathrm{HCl}(1: 5 \mathrm{w} / \mathrm{v})$ was added. The mixture was incubated at $40{ }^{\circ} \mathrm{C}$ and $40 \mathrm{rpm}$ over the course of $24 \mathrm{~h}$. After this, it was left to rest for $30 \mathrm{~min}$ and deproteinization was performed, $1300 \mathrm{~mL}$ of $4 \%$ $\mathrm{NaOH}$ was added followed by incubation at $40{ }^{\circ} \mathrm{C}$, and after $24 \mathrm{~h}$, the excess $\mathrm{NaOH}$ was discarded. Finally, the sample was bleached by adding $200 \mathrm{~mL}$ 
of $4 \%$ sodium hypochlorite, allowing it to react for $2 \mathrm{~h}$, washed with distilled water to remove chlorine residues and dried in an oven (Yamato DX302) at $75{ }^{\circ} \mathrm{C}$ for $9 \mathrm{~h}$. Chemical form of glucosamine that was proposed to produce was $\mathrm{Gluc}-\mathrm{HCl}$, and it was expected to recover $\mathrm{N}$-acetyl-D-glucosamine.

Gluc-HCl and N-acetyl-D-glucosamine extraction Extraction with single enzymes - pectinase, lipase, or hemicellulase

A sample of $2.0 \mathrm{~g}$ of chitin was weighed for each of the three enzymes tested (pectinase, lipase or hemicellulase) with $0.5 \mathrm{~g}$ of them mixed. Then, $200 \mathrm{~mL}$ of a phosphate buffer solution $(\mathrm{pH}$ 7.0) was added to each of the tests. Samples were incubated at $40{ }^{\circ} \mathrm{C} \pm 5{ }^{\circ} \mathrm{C}$ with constant agitation $(40 \mathrm{rpm})$ for $1 \mathrm{~h}$. Afterwards, samples were cooled down to room temperature over the course of $2 \mathrm{~h}$, bleached with sodium hypochlorite $(0.053 \mathrm{M})$ for $1.5 \mathrm{~h}$ and filtered through washing vigorously with distilled water with the filtrate being recovered. The filtrated solution was completely dried on a heating plate at $75^{\circ} \mathrm{C}$ (SHINYA et al., 2001; DONG-XIA et al., 2008; XIA et al., 2008). The extraction yield was calculated as follows:

\section{Equation 1}

Extraction yield $=($ Weight of final solid extract / weight of chitin) ${ }^{*} 100$

Finally, the concentration of Gluc- $\mathrm{HCl}$ and $\mathrm{N}$-acetyl-D-glucosamine in the extract was analyzed by High-Performance Liquid Chromatography (HPLC) as described in the corresponding section. All trials were completed in triplicate.

\section{Enzymatic conjugation}

A selected combination of enzymes was assessed in terms of activity according to the yields of dry extract of chitin (from the crab exoskeletons). Each enzyme (Sigma-Aldrich) was previously tested for their appearance of color and texture to determine quality. The selected combinations were: hemicellulase-cellulase and lipase-pectinase. The procedure started by weighing $2 \mathrm{~g}$ of chitin and $0.2 \mathrm{~g}$ of enzymes ( $0.1 \mathrm{~g}$ of each), with 200 $\mathrm{mL}$ of phosphate buffer solution $\mathrm{pH} 7$ added, then homogenization by agitation at $40 \mathrm{rpm}$ and $37^{\circ} \mathrm{C} \pm$ $1{ }^{\circ} \mathrm{C}$ for $24 \mathrm{~h}$. Thereafter, the mixture was allowed to stand until the product precipitated. At this point, it was bleached with $38 \%$ sodium hyplochlorite for $90 \mathrm{~min}$ and washed thoroughly with distilled water to eliminate residual chlorine. It was next filtered and washed again to recover Gluc- $\mathrm{HCl}$, after which it was subjected to evaporation in a heating plate at $75^{\circ} \mathrm{C}$ for $1.5 \mathrm{~h}$. (JEEN-KUAN et al., 2010). The extraction yield was calculated (Eq. 1; as previously described) and the concentration of Gluc-HCl and N-acetyl-Dglucosamine was evaluated by HPLC. All trials were conducted in triplicate.

\section{Chemical method $A$}

The extraction of Gluc- $\mathrm{HCl}$ and $\mathrm{N}$-acetylD-glucosamine from crab exoskeletons was carried out chemically by two methodologies; method A was adapted from SIBI et al. (2013; with some modifications) and is described as follows: chitin was treated with a $2 \mathrm{~N} \mathrm{NaOH}$ solution to remove the acetyl groups, at room temperature, during $8 \mathrm{~h}$ in a shaker. The resulting chitosan was washed twice, first with potable water until neutrality and then with distilled water, and it was finally dried in the sun. The extract obtained from the chitosan material was finely ground and hydrolyzed with concentrated $\mathrm{HCl}$ during the course of $75 \mathrm{~min}$ at $90^{\circ} \mathrm{C}$. The material was dissolved in water and bleached with activated carbon. Next, the solution was filtered and filtrate was evaporated at $45{ }^{\circ} \mathrm{C}$ to recover the glucosamine crystals. Three replicates of the present procedure were assessed. The crystals were washed and dried at $50{ }^{\circ} \mathrm{C}$ in a hot air oven for resuspension and chromatographic analysis by HPLC. The yield of solid extract was also calculated, according to Eq. 1 previously described.

\section{Chemical method B}

Chemical method B was adapted from JAVID et al. (2007) and consisted of the following steps: the chitin obtained in the process of demineralization, deproteinization and bleaching of the crab exoskeletons was hydrolyzed by boiling under reflux with concentrated $\mathrm{HCl}$ for 20 min until it was completely dissolved. The solution was left to rest for $14 \mathrm{~h}$ until the glucosamine precipitated. After collecting the filtrate, it was washed with cold water $\left(5^{\circ} \mathrm{C}\right)$ and recrystallized (heated by oven at $60{ }^{\circ} \mathrm{C}$ ). Three replicas of the present procedure were analyzed. The extraction yield was calculated with the previous equation and the presumably Gluc- $\mathrm{HCl}$ and $\mathrm{N}$-acetyl-D-glucosamine were re suspended, at which point chromatographic analysis was carried out.

\section{Microbiological method}

The microbiological method was based on that reported by SITANGGANG et al. (2012) with some modifications. The first step of this methodology was to carry out the bacterial development or development in LB-enriched medium for Bacillus subtilis strain, ATC6633. A bioreactor designed at 
the MexiFood S.A. company was inoculated with 1 $\mathrm{L}$ of the culture medium and $15 \mathrm{~mL}$ of phosphate buffer $\mathrm{pH} 7$, plus $200 \mathrm{~g}$ of substrate (chitin) was added. It was subjected to constant agitation at 40$50 \mathrm{rpm}$ and at $37 \pm 5^{\circ} \mathrm{C}$ with induced aeration. After $24 \mathrm{~h}$, the product was separated by sedimentation, decolorized (with $4 \%$ sodium hypochlorite), washed with distilled water, filtered and dehydrated at 70 $\pm 5^{\circ} \mathrm{C}$, with the yield obtained calculated with the aforementioned formula and a chromatographic assay performed to determine the concentration of Gluc-HCl and N-acetyl-D-glucosamine. The assay was completed in triplicate.

Determination of $\mathrm{Gluc}-\mathrm{HCl}$ and $\mathrm{N}$-acetyl-Dglucosamine by High-Performance Liquid Chromatography

For the chromatographic identification and quantification of Gluc-HCl and N-acetyl-Dglucosamine, the methodology reported by SIBI et al. (2013) was adhered to. The obtained extracts were re suspended at a concentration of $2 \mathrm{mg} /$ $\mathrm{mL}$ in a mixture of orthophosphoric acid $(\mathrm{pH} 2.5)$ : acetonitrile (70:30), used as a mobile phase; $1: 10$ or 1:20 dilutions were made as required, for each sample, and a homogeneous aliquot was taken and placed in 2-mL amber vials and injected into the chromatographic system. A Dionex U-3000 High Resolution Liquid Chromatography (HPLC) system was employed - this chromatograph is equipped with a quaternary pump system, W-3000 automatic injector, column oven and a diode array detector (DAD). The analytical separation column utilized was a Zorbax Eclipse XDB-C18 (4.6 x $250 \mathrm{~mm}$ and $5 \mu \mathrm{m}$; Agilent Technologies). For the elution of the compounds, an isocratic gradient composed of orthophosphoric acid (pH 2.5): acetonitrile (70:30) was used and the flow rate was $0.6 \mathrm{~mL} / \mathrm{min}$. The injection volume was 10 $\mu \mathrm{L}$ and detection was through UV absorbance at 195 $\mathrm{nm}$. Identification of the compounds was carried out based on the comparison of the retention times and absorption spectra with pre-run Gluc- $\mathrm{HCl}$ (Rockville UPS; USA, No. CAT.1294207) and N-Acetyl-Dglucosamine (Sigma, No. CAT.A4106-25 g) standards prepared to a concentration of $1 \mathrm{mg} / \mathrm{mL}$. In both cases of the quantification of the compounds, standard curves were made with a minimum $\mathrm{R}$ of 0.9900 . The concentration of Gluc-HCl and N-Acetyl-Dglucosamine was reported in $\mathrm{mg} / \mathrm{g}$.

\section{Statistical analysis}

Statistical analysis was carried out with the Statistical Package for the Social Sciences (SPSS);
IBM, Chicago, USA) v.20 program with the following statistical tests: analysis of variance (ANOVA) table, variance test and mean table with minimum significant difference intervals (Tukey $\mathrm{P} \leq 0.05$ ).

\section{RESULTS AND DISCUSSION}

Theyield indicates that there are statistically significant differences $(\mathrm{P} \leq 0.05)$ between the various evaluated treatments; the microbiological method exhibited the highest yield (94.43\%), followed by the enzymatic method with pectinase $(94.12 \%)$ that did not differ statistically from hemicellulase and lipase yields (92.4 and $91.03 \%$, respectively). Chemical method A (hydrolysis with $\mathrm{NaOH}$ ) featured the lowest yield with $28.53 \%$ solid extract from chitin. This agrees with what is widely reported in the literature and has been documented by MUZZARELLI et al. (1999), where it is mentioned that enzymatic methods offer better glucosamine yields than chemical methods. SASHIWA et al. (2003) described yields of N-Acetyl-D-glucosamine of between 84 and $100 \%$ using individually the enzymes hemicellulase, pectinase and lipase. The Gluc- $\mathrm{HCl}$ was identified and quantified by HPLC-DAD; and although, it was not definitive that N-acetyl-D-glucosamine was identified in some samples, because it also has commercial importance, so it was quantified in the same way as Gluc-HCl. As can be seen in Table 1, the highest concentration of Gluc- $\mathrm{HCl}$ was obtained when the lipase was used for the hydrolysis of chitin ( $94.14 \mathrm{mg} / \mathrm{g}$ of chitin), with statistically significant differences being observed $(\mathrm{P} \leq 0.05)$ that separated the lipase treatment widely (statistical group) from the rest of the treatments. The second most effective method was the microbiological one with a yield of Gluc- $\mathrm{HCl}$ of $45.76 \mathrm{mg} / \mathrm{g}$ of chitin, being statistically different from the remainder of the procedures. Extraction with both chemical methods yielded the lowest concentration of Gluc- $\mathrm{HCl}$, specifically approximately $7.3 \mathrm{mg} / \mathrm{g}$ of chitin in both cases.

Figure 1 depicts the chromatograms obtained from the standards of both compounds, and on the $\mathrm{x}$-axis can be observed the retention time for the standards elution that was 3.4 and 3.46 for N-AcetylD-glucosamine and Gluc- $\mathrm{HCl}$, respectively; and, on the $y$-axis, the absorbance of light in mAU is represented, where at higher concentrations of the compound, a greater absorption of light is established, in this case ultraviolet $(195 \mathrm{~nm})$. 


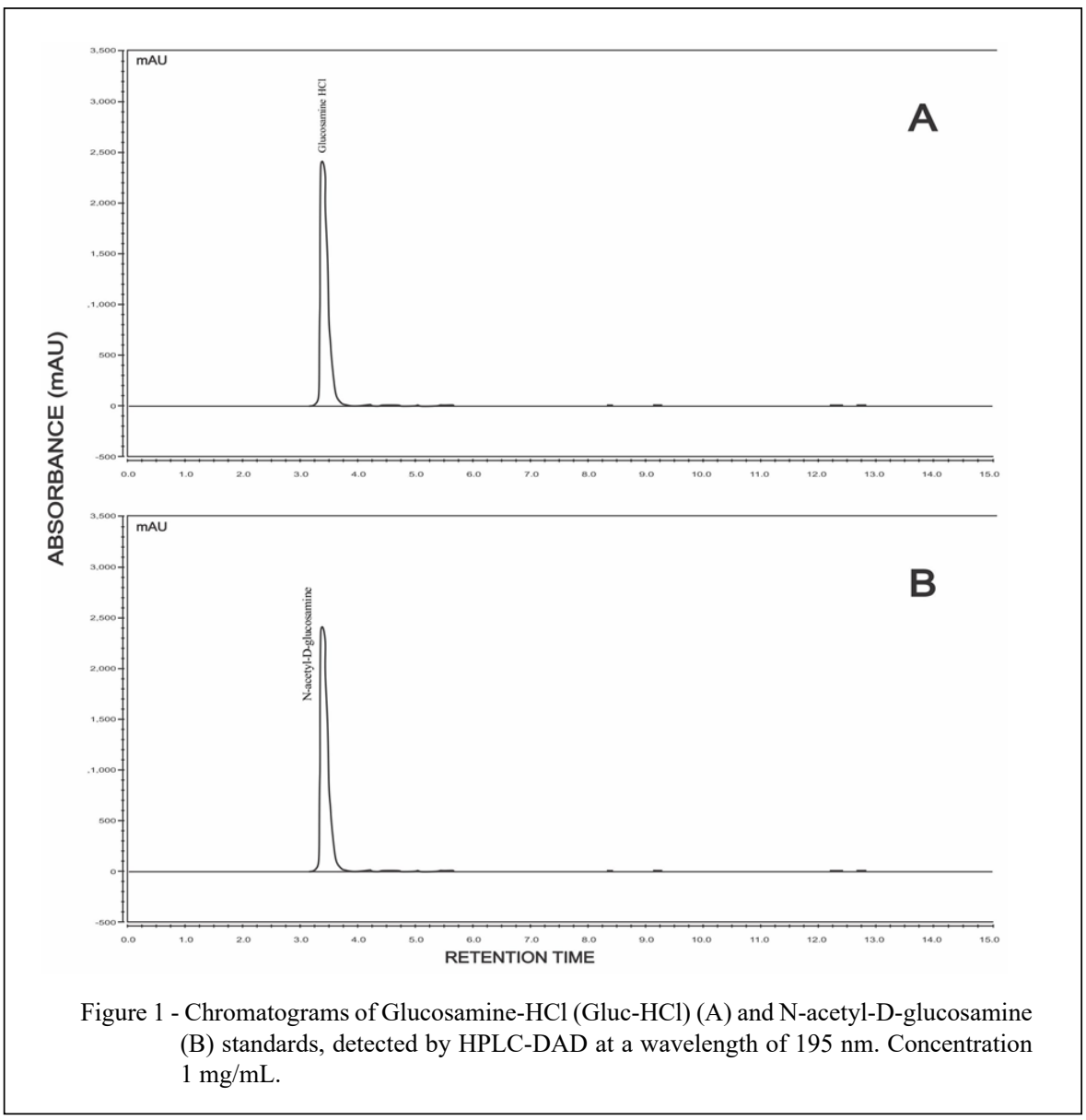

The chromatograms with both chemical methods are depicted in figure 2; additionally, in figures 3 and 4, the chromatograms of the samples hydrolyzed with lipase, pectinase, hemicellulase, hemicellulase-cellulase, lipase-pectinase and with the microbiological method are shown. In these chromatograms, other signals may be observed, potentially corresponding to impurities from the extraction or a low molecular weight derivative of the hydrolysis of chitin.

The samples of panels $\mathrm{A}$ and $\mathrm{C}$ were diluted 1:10 prior to injection and that of panel $\mathrm{C}$ was injected at a 1:20 dilution. Concentration values of Gluc-HCl obtained with the chemical methods of this work (slightly more than $7 \mathrm{mg} / \mathrm{g}$ ) are higher than that reported by SIBI et al. (2013) $(3.32 \mathrm{mg} / \mathrm{g}$ of Gluc-HCl). They used a chemical method from the shell of Penaeus monodon, which is very similar to that used in the present research; but, when utilizing raw material from two species of Portunus crab, concentrations of Gluc- $\mathrm{HCl}$ were similar to those with conjugated enzymatic methods, so it can be suggested that the degree of hydrolysis of chitin or chitosan depends on the material premium being used (SIBI et al., 2013). As already mentioned, the treatment that produced the best results was that with enzymatic lipase for the degradation of chitin. LEE et al. (2008) reported that the use of commercial lipase was effective for obtaining quito-oligosaccharides and glucosamine from chitosan, showing this enzyme's endo- and exolitic activity. Regarding treatments with enzymatic conjugation, both the use of the hemicellulase-cellulase and lipase-pectinase combination resulted in more promising outcomes than hemicellulase and pectinase - individually and statistically, they were in different groups. This agrees with SASHIWA et al. (2003), who noted that combining two types of enzymes - cellulase plus lipase - produced better glucosamine yields than using enzymes individually and recommended 


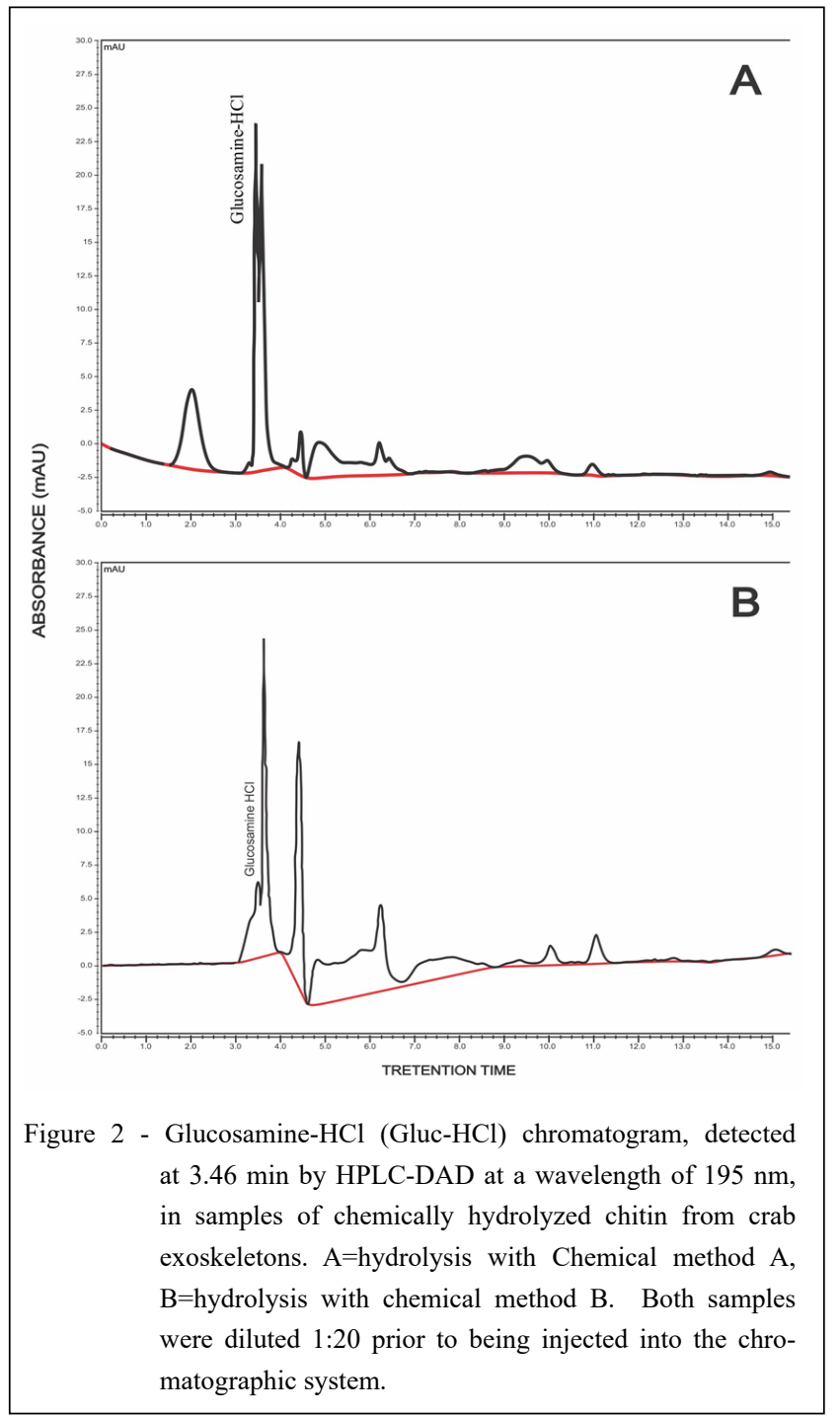

the utility of these enzymes for the production of $\mathrm{N}$-acetyl-glucosamine from $\alpha$ - and $\beta$-chitin.

Regarding the employment of the microbiological method, it was documented that previously, different biotransformation systems have been reported for use with microorganisms for glucosamine production, such as: Aeromonas caviae DYU-BT4 (obtaining $7.8 \mathrm{~g} / \mathrm{L}$ ) + Chitinases bacterial (with glucosamine yields up to $98 \%$ ) (CHERN et al., 2004; LI et al., 2005). In this research, the microbiological method with Bacillus subtilis featured the second highest concentration of Gluc$\mathrm{HCl}$ with more than $45 \mathrm{mg}$ of Gluc- $\mathrm{HCl} / \mathrm{g}$ of chitin.
Bacillus has been the source of a number of enzymes for different purposes, including chitinolytic activities (SALEEM et al., 2016), and is a consistent candidate for use in biotransformation methods.

The N-Acetyl-D-glucosamine could only be observed with three of the eight treatments. In the samples where enzymatic methods were applied involving lipase and/or pectinase for the hydrolysis of chitin, the concentrations were very small (0.16$2.97 \mathrm{mg} / \mathrm{g}$ of chitin). It was also the method where lipase was used individually and had the highest concentration of this form of glucosamine (as with Gluc- $\mathrm{HCl})$ and was statistically different $(\mathrm{P} \leq 0.05)$ 


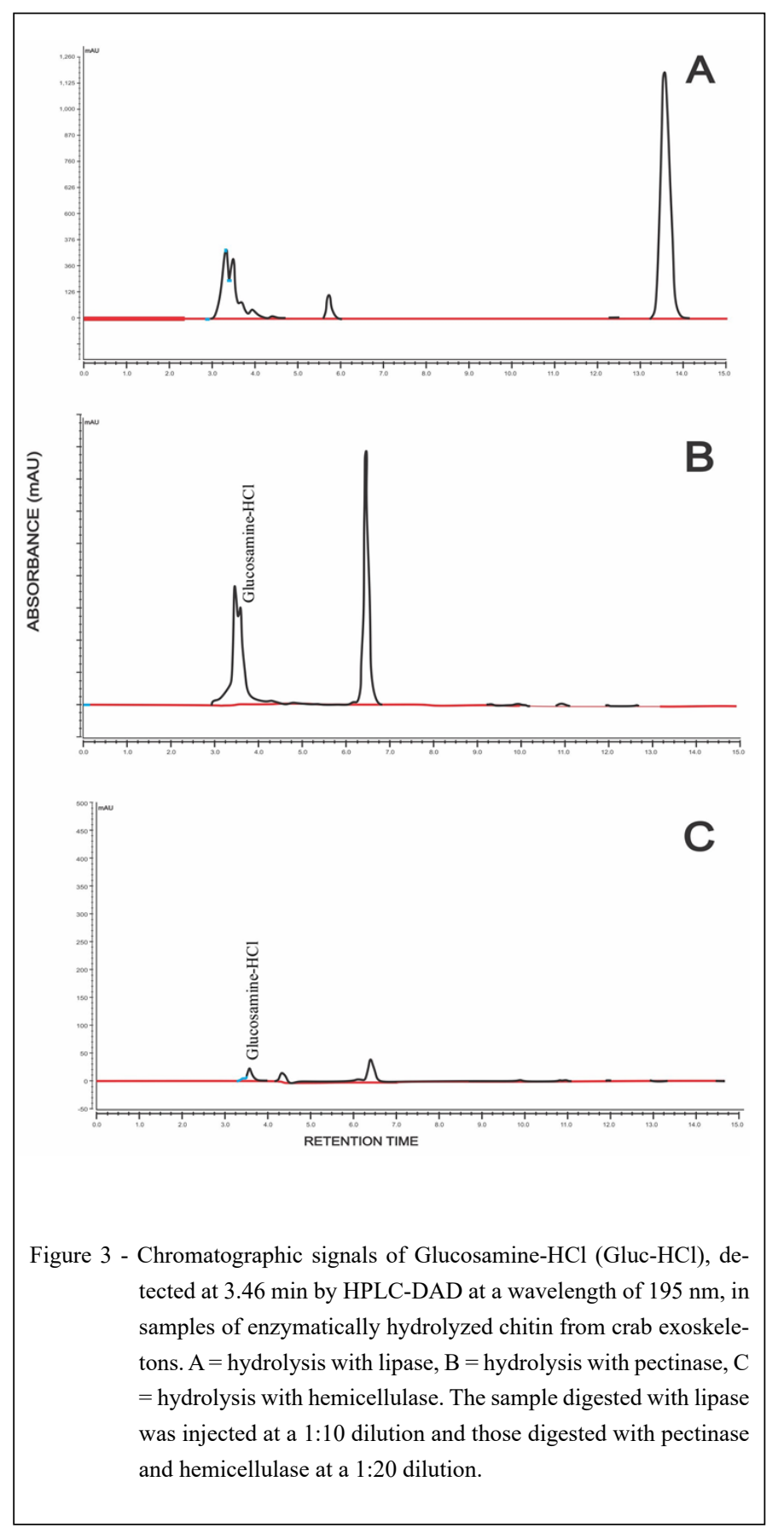

from the other two treatments leading to N-AcetylD-glucosamine. SASHIWA et al. (2003) obtained $\mathrm{N}$-Acetyl-D-glucosamine from chitin with the use of various commercial enzymes, such as cellulase, hemicellulase, papain, lipase and pectinase, obtaining robust results after eight days of hydrolysis. In addition, it has been put forth that exochitinases act progressively through the reducing end of chitin, releasing chitobiose and $\mathrm{N}$-acetyl-glucosamine; this is what was observed in the present research with lipase. 


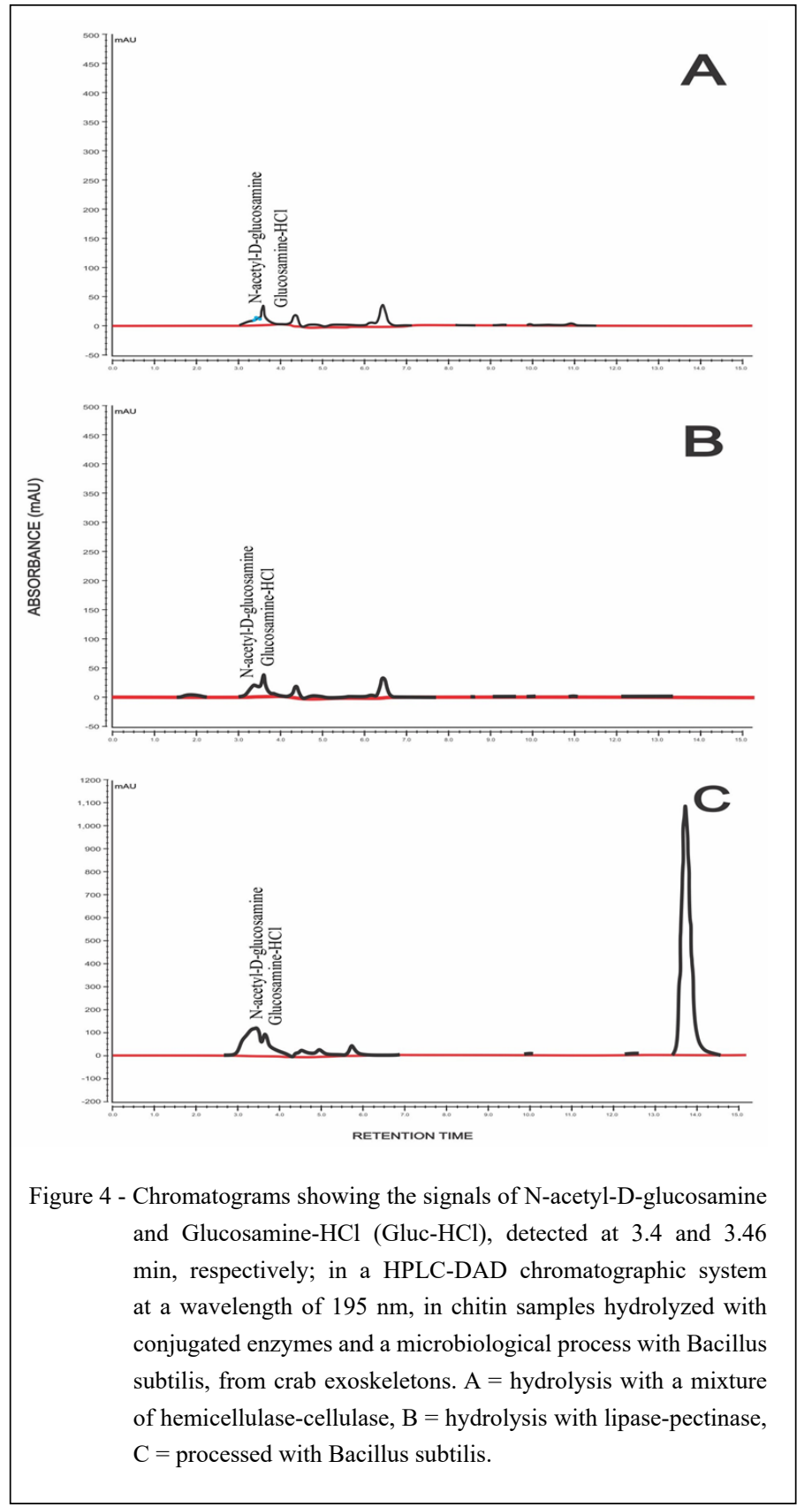

\section{CONCLUSION}

Two chemical treatments, five enzymatic and one microbiological treatment were evaluated to obtain glucosamine hydrochloride (Gluc-HCl) from the chitin of crab exoskeletons (Callinectes bellicosus). The treatments with which the highest concentrations of Gluc- $\mathrm{HCl}$ were obtained, in descending order, were: lipase, microbiological, lipase-pectinase, hemicellulasecellulase, hemicellulase, pectinase, Chemical A and Chemical B. In terms of yield, the best treatments in descending order were: pectinase, microbiological, hemicellulase, lipase, chemical B, lipase-pectinase, hemicellulase-cellulase and chemical A. The treatments that are proposed as viable procedures for obtaining Gluc- $\mathrm{HCl}$ are those that involve the use of the enzyme lipase and the microbiological 
method - they are ecofriendly procedures and could add value to crab's productive chain.

\section{ACKNOWLEDGEMENTS}

To Quality Control and Research Laboratory of the crab processing company Mexi Food S.A. of C.V. and the Department of Agricultural Biotechnology of CIIDIR-IPN, Sinaloa Unit.

\section{BIOETHICS AND BIOSSECURITY COMMITTEE APPROVAL}

We authors of the article entitled "Sustainable production with obtaining glucosamine from crab exoskeletons" declared, for all due purposes, the project that gave rise to the present data of the same has not been submitted for evaluation to the Ethics Committee of the University /Research Institute "Instituto Politécnico Nacional. Centro Interdisciplinário de Investigación para el Desarrollo Integral Regional", but we are aware of the content of the Brazilian resolutions of the National Council for Control of Animal Experimentation - CONCEA "http://www.mct.gov.br/index.php/content/view/310553.html" if it involves animals.

Thus, the authors assume full responsibility for the presented data and are available for possible questions, should they be required by the competent authorities.

\section{DECLARATION OF CONFLICT OF INTERESTS}

The authors declare no conflict of interest. The founding sponsors had no role in the design of the study; in the collection, analyses, or interpretation of data; in the writing of the manuscript, and in the decision to publish the results.

\section{AUTHORS' CONTRIBUTIONS}

The authors contributed equally to the manuscript.

\section{REFERENCES}

ANASTASSIADES, T., et al. N-acylated glucosamines for bone and joint disorders: effects of N-butyrylglucosamine on ovariectomized rat bone. Transl. Res., v.162, p.93-101, 2013. Available from: $<$ https://www.ncbi.nlm.nih.gov/pubmed/23680489>. Accessed: Apr. 20, 2019. doi:10.1016/j.trsl.2013.04.002

CHERN, L.L., et al. Chitinibactertainanensis Gen. nov. sp. nov., to chitin-degrading aerobe from soil in Taiwan. Int. J. Syst. Evol. Microbiol., v.54, p.1387-1391, 2004. Available from: <https:// ijs.microbiologyresearch.org/content/journal/ijsem/10.1099/ ijs.0.02834-0>. Accessed: Apr. 20, 2019. doi: 10.1099/ijs.0.02834-0.

CONAPESCA, COMISIÓN NACIONAL DE ACUACULTURA Y PESCA. Jaiba, entre los diez productos pesqueros de mayor volumen y valor en México. <https://www.gob.mx/conapesca/articulos/jaibaentre-los-diez-productos-pesqueros-de-mayor-volumen-y-valor-enmexico?idiom=es>, 2018. Accessed: Apr. 20, 2019.

ELIEH-ALI-KOMI, D. \& HAMBLIM, M.R., (2016) Chitin \& Chitosan: Production and application of versatile biomedical nanomaterials. Int. J. Adr. Res. 4(3), 411. Accessed: Apr. 20, 2019.
FAKHRAD, L. \& RENGIN, E. 2018. Chitooligosaccharides and their biological activities: a comprehensive review. Carhohydr. Polym. 184:243-254. Available from: <https://www.ncbi.nlm.nih. gov/pubmed/29352917>. Accessed: Apr. 20, 2019. doi:10.1016/j. carbpol.2017.12.067.

HASSAINIA, A., et al. Chitin from Agaricus bisporus: Extraction and characterization. Int. J. Biol. Macromol., v.117, p.1334-1342. Available from: <https://europepmc.org/abstract/med/29197571>. Accessed: Apr. 20, 2019. doi: 10.1016/j.ijbiomac.2017.11.172

HENROTIN, Y., et al. Is there any scientific evidence for the use of glucosamine in the management of human osteoarthritis? Arthritis Res. Ther., v.14, p.201, 2012. Available from: <https://arthritisresearch.biomedcentral.com/articles/10.1186/ar3657>. Accessed: Apr. 20, 2019. doi: 10.1186/ar3657.

JAMIALAHMADI, K., et al. Protective effects of glucosamine hydrochloride against free radical-induced erythrocytes damage. Environ. Toxicol. Pharmacol., v.38, p.212-219, 2014. Available from: $\quad<$ https://www.ncbi.nlm.nih.gov/pubmed/24959958>. Accessed: Apr. 20, 2019. doi: 10.1016/j.etap.2014.05.018

JAVID, S., et al. Preparation of glucosamine from exoskeleton of shrimp and predicting production yield by response surface methodology. J. Agric. Food Chem, v.55(6), p.2246-2250, 2007. Available from: $<$ https://pubs.acs.org/doi/abs/10.1021/jf062983a $>$. Accessed: Apr. 20, 2019. doi: 10.1021/jf062983a.

JEEN-KUAN, C., et al. $N$-Acetylglucosamine: Production and Applications. Mar. Drugs, v.8, p.2493-2516, 2010. Available from: <https://www.mdpi.com/1660-3397/8/9/2493>. Accessed: Feb. 15, 2019. doi: 10.3390/md8092493.

LEE, D.X., et al. Enzymatic preparation of chitooligosaccharides by commercial lipase. Food Chemistry, v.111, p.291-295, 2008. Available from: <https://pubag.nal.usda.gov/catalog/731822>. Accessed: Apr. 20, 2019. doi: 10.1016/j.foodchem.2008.03.054.

LI, Y.L., et al. Screening of a microbe to degradate chitin. Taiwan. J. Agric. Chem. Food Sci., v.43, p.410-418, 2005. (2): 193-198 (2018) Available from: <http://researcherslinks.com/ current-issues/Screening-and-Identification-of-Chitin/26/1/1854/ html>. Accessed: Apr. 20, 2019. doi: 10.17582/journal. pujz/2018.33.2.193.198

MILLER, K.L.; CLEGG, D.O. Glucosamine and chondroitin sulfate. Rheum. Dis. Clin. North Am., v.37, p.103-118, 2011. Available from: <https://www.ncbi.nlm.nih.gov/ pubmed/21220090>. Accessed: Apr. 20, 2019. doi: 10.1016/j. rdc.2010.11.007

MUZZARELLI, R.A.A., et al. Enzymatic depolymerization of chitins and chitosans. Human Press Inc: New Jersey, USA. 1999.

NIDHEESH, T., et al. Enzymatic degradation of chitosan and 324 productions of D-glucosamine by solid substrate fermentation of 325 exo-Beta-D-glucosaminidase (exochitosanase) by Penicillium decumbens. 326 CFRNT15. Internat. Biodeterior. Biodegradation, v.97, p.97-106, 2015. Available from: <http:/ agris.fao.org/agrissearch/search.do?recordID=US201700112886> . Accessed: Apr. 20, 2019.

ROVATI, L.C., et al. Effects of glucosamine sulfate on the use of rescue non-steroidal anti-inflammatory drugs in knee osteoarthritis: results from the pharmaco-epidemiology of GonArthroSis 
(PEGASus) study. Semin. Arthritis Rheum., v.45, p.1-8, 2015. Available from: <https://www.sciencedirect.com/science/ article/pii/S004901721500270X $>$. Accessed: Jan. 18, 2019. doi: 10.1016/j.semarthrit.2015.10.009.

SAGARPA. Statistical yearbook of aquaculture and fisheries National Commission of Aquaculture and Fisheries. Mexico. Retrieved on January 22, 2017 Available from: < http://www. conapesca.sagarpa.gob.mx>. Accessed: Apr. 25, 2011.

SALEEM, F., et al. Molecular characterization of Bacillus chitinase for bioconversion of chitin waste. Nat. Prod. Res., v.6, p.720-723, 2016. Available from: <https://www.tandfonline.com/doi/full/10 $.1080 / 14786419.2015 .1040789>$. Accessed: Mar. 10, 2019. doi: $10.1080 / 14786419.2015 .1040789$.

SASHIWA, H., et al. Enzymatic production of N-AcetylD-glucosamine from chitin. Degradation study of $\mathrm{N}$-acetylchitooligosaccharide and the effect of mixing of crude enzymes. Carbohydr. Polym., v.51, p.391-395, 2003. Available from: $\quad<$ https://www.researchgate.net/publication/229406228 Enzymatic production of $\mathrm{N}$-acetyl-D-glucosamine from chitin Degradation_study_of_N-acetylchitooligosaccharide_and the effect of mixing of crude enzymes $>$. Accessed: Apr. $20, \overline{2} 019$ doi: $10.1016 / \mathrm{S} 0144-\overline{8} 617(02) 00192-3$.

SHAHIDI, F., SYNOWIECKI, J. Isolation and characterization of nutrients and value-added products from snow crab (Chinoecetes opilio) and shrimp (Pandalus borealis). J. Agric. Food Chem., v.39, p.1527-1532, 1991. Available from: < https://pubs.acs.org/ doi/10.1021/jf00008a032>. Accessed: Apr. 20, 2019. doi: 10.1021/ jf00008a032.

SHIN-YA, Y., et al. Effects of N-acetylation degree on $\mathrm{N}$-acetylated chitosan hydrolysis with commercially available and modified pectinases. Biochem. Eng. J., v.7, p.85-88, 2001. Available from: $<$ https:/plu.mx/plum/a/?doi=10.1016/S1369-703X(00)00129-7> Accessed: Mar. 20, 2019. doi: 10.1016/S1369-703X(00)00129-7

SIBI, G., et al. Preparation of glucosamine hydrochloride from crustacean shell waste and it's quantitation by RP-HPLC. Eur .J. Sci. Res., v.8, p. 63-67, 2013.

SITANGGANG, A.B., et al.,. Aspects of glucosamine production using microorganism. Int. Food Res. J. (Malaysia). v. 19, p.393404. 2012. Available from: 10.5829/idosi.aejsr.2013.8.2.7381 Accessed: Jan. 12, 2019.

SUN, Y., et al. Preparation of D-glucosamine by hydrolysis of chitosan with chitosanase and $\beta$-D-glucosaminidase. Int. J. of Biol. Macromol., v.61, p.160-163, 2013. Available from: <http:// europepmc.org/abstract/med/23817094>. Accessed: Mar. 15, 2019. doi: 10.1016/j.ijbiomac.2013.06.033.

XIA, W., et al. Advance in chitosan hydrolysis by nonspecific cellulases. Bioresour Technol. v.99(15), p.67516762. 2008. Available from: <https://www.ncbi.nlm.nih.gov/ pubmed/18328693>. Accessed: Jan. 10, 2019. doi: 10.1016/j. biortech.2008.01.011.

$\mathrm{XU}, \mathrm{Y}$, et al. Chitin purification from shrimp wastes by microbial deproteination and decalcification. Appl. Microbiol. Biotechnol., v.79, p.687-697, 2008. Available from: <https://link.springer.com/ article/10.1007/s00253-008-1471-9>. Accessed: Apr. 20, 2019. doi: $10.1007 / \mathrm{s} 00253-008-1471-9$

YALPANI, M.; PANTALEONE, D. An examination of the unusual susceptibilities of aminoglycans to enzymatic hydrolysis. Carbohydr. Res., v.256, p.159-161, 1994. Available from: $<$ https:// www.sciencedirect.com/science/article/pii/0008621594842353>. Accessed: Feb. 21, 2019. doi: 10.1016/0008-6215(94)84235-3. 